\title{
Gap in Trade Companies’ Perception of Consumers’ Purchasing Processes
}

\author{
Marcin Gąsior \\ Lublin University of Technology \\ E-Mail: gasior.m@gmail.com \\ Łukasz Skowron \\ Lublin University of Technology \\ E-Mail: lukasz.m.skowron@gmail.com
}

\begin{abstract}
Consumer behaviour is an inherent element of marketing science. It provides a significant contribution to the cognition of the mechanisms that govern the units that select and purchase goods and services. At the same time a question arises, the extent to which these behaviours are known to companies and the extent to which this knowledge is used as a foundation for creating marketing and sales strategies become apparent. The purpose of this article is to present selected results of research showing, based on the example of the Polish information technologies market, the gap that exists between the perception of consumer behaviour by conventional and on-line trade companies, and its actual/real course.
\end{abstract}

Keywords: Consumers' Expectations, Consumer Behavior, Company's Knowledge, Retail

\section{INTRODUCTION}

Behaviour of a consumer constitutes any actions undertaken by people during obtaining, using, and disposing of products and services, which can include actions involving the purchase or the receipt of a product, place, manner and time of its use, and the method of disposal of acquired goods (Blackwell, Miniard, and Engel, 2001). A similar approach has been presented by other authors. Solomon defined consumer behaviour more explicitly, as processes taking place at the moment when an 
individual or a group selects, purchases, uses and gets rid of products, services, ideas or experiences necessary to satisfy their needs and desires (Solomon, 2007). Antonides and van Raaij consider consumer behaviour to be a set of mental and physical activities concerning orientation, buying, using and getting rid of products allowing the consumer to operate as well as achieve their goals and values (Antonides, van Raaij, 1998). MacInnis and Folkes describe it as an acquisition, consumption and disposal of marketplace products, services and experiences by people operating in consumer role (MacInnis, Folkes, 2010), while Kardes, Cronley and Maria additionally includes consumer's emotional, mental and behavioural responses that precede, determine or follow this activities (Kardes, Cline, Cronley, 2011).

Considering the meaning of consumer processes in making marketing and managerial decisions, a question may arise concerning the knowledge of those processes or, at least, an awareness of them among the companies that operate on various markets. At this point, it should be noted that this issue is discussed in the literature from a wide, strategic point of view (Piercy, 2009; Rowley 2002), as well as from the perspective of knowledge management (Wilhelm, Gueldenberg, and Güttel, 2013; Wilde, 2011; Etemad, 2004). The literature also discusses this issue from the perspective of assessing companies' tendencies to inform themselves concerning the opinions of consumers (Chua and Banerjee, 2013; Sinkula, 2002) or concerning ecommerce-oriented patterns of behaviour (Rowley and Slack, 2001). However, although several research papers on this subject are available (McLean and Blackie, 2004), there are no research results available that confirm the level of the possessed knowledge or that indicate its functional shortcomings.

With the assumptions that have been mentioned, it seems reasonable to introduce the concept that a potential gap exists that can be used to determine the discrepancy between the real course of the purchasing process, and its image as identified by a particular company or, from a general perspective, all of the companies in the considered market. Measurement of such a gap may constitute a convenient basis for diagnosing the potential weaknesses of a given company. These could include the areas that enable both better adjustment of the company's long-term strategy and that enable the optimization of the activities conducted on an on-going basis that consider the actual behaviours of consumers, their expectations, and requirements. This article attempts to answer the question concerning whether such a gap exists and to ascertain whether it is possible to evaluate its causes and nature. 


\section{RESEARCH PROCEDURE}

An attempt to demonstrate the existence of the above-mentioned gap was based on research related to the behaviour of customers of the Polish IT market. The research was focused on two aspects of this market, i.e., 1) primarily covering a group of consumers who purchased products from the IT market and 2) covering a group of employees of companies involved in both storefront and Internet retail sales of IT products.

An interactive questionnaire was used as a research tool to acquire consumers' opinions. The scope of the variables (290 included) that were measured was defined on the basis of an analysis of constituent elements of different models of consumers' behaviours (Bettman, 1979; Rosania, 1995; Kotler and Keller, 2006; Blackwell, Miniard, and Engel, 2001), and on the basis of a critical analysis of the literature on the subject. Based on a series of focused group interviews (FGI), the variables were evaluated and made more specific during the qualitative study. Several additional variables were measured to obtain a profile of the participants in the study.

The study of consumers consisted of a survey of 998 respondents selected by quota sampling (Zikmund, Babin, 2013) from potential Polish consumers who use the Internet. The quotas were designated based upon the data from the Polish Central Statistical Office (“Wykorzystanie technologii...", 2010) in such a way that the structure of the study would reflect the structure of the population that was assessed (Polish users of the Internet). Due to the fact that the study was concerned with Internet users, it should be noted that the selection of the study group by probabilistic sampling was very difficult, if not impossible (Furrer and Sudharshan, 2001; Bethlehem, 2010).

Primarily, the availability of the IT products on the Internet was the reason for conducting the study among Internet users. The second argument was the realization that almost every household in Poland has a computer and Internet access (“Oszacowanie przyszłej...”, 2010). Thus, we assumed that being a consumer in the IT market implies that one also uses the Internet. We should also emphasize the advantages related to lower cost, speed, and efficiency of this type of study.

The part devoted to the companies (54 entities) of the considered market contained a questionnaire that included substantially the same variables as the consumers' questionnaire. The only difference was that the same questions were formulated in a manner that enabled the measurement of the opinions of employees related to the areas of consumer behaviour covered by the research. This approach made it possible to compare the assessments of the two groups and, hence, indicate 
discrepancies between the preferences of consumers and the perception of their preferences by the entrepreneurs who operate in the market.

\section{RESULTS}

In order to demonstrate the existence of the above-mentioned gap and to diagnose its nature, three areas of consumer behaviour were used, i.e., 1) the scope of their expectations regarding the course of the transaction, 2) the factors that determined how they selected where to make purchases, and 3) the assessment of the importance of the customers' perceptions of the level of customer service they received. Factors from all of the areas were measured in a consumer questionnaire, and questionnaire for the companies on a 9-degree numeric scale. The following tables present only those factors for which the differences exceeded the value of 0.5 .

The first area that was analyzed was the expectations of consumers while they were involved in a purchasing transaction (12 variables). Table 1 presents the average assessments, their importance, and their standard deviations for both groups that were tested.

Table 1 Expectations of Consumers

\begin{tabular}{|c|c|c|c|c|c|c|}
\hline \multirow{2}{*}{ Factor } & \multicolumn{2}{|c|}{$\begin{array}{l}\text { Ratings of } \\
\text { consumers }\end{array}$} & \multicolumn{2}{|c|}{$\begin{array}{l}\text { Ratings of } \\
\text { companies }\end{array}$} & \multirow{2}{*}{$\begin{array}{c}\text { Difference } \\
\text { in average } \\
\text { ratings }\end{array}$} & \multirow{2}{*}{$p$-value } \\
\hline & Avg. & $\begin{array}{l}\text { Std. } \\
\text { dev. }\end{array}$ & Avg. & $\begin{array}{l}\text { Std. } \\
\text { dev. }\end{array}$ & & \\
\hline $\begin{array}{l}\text { Availability of products "right } \\
\text { away" }\end{array}$ & 7.46 & 1.73 & 6.35 & 1.66 & 1.11 & $<0.001$ \\
\hline $\begin{array}{l}\text { Possibility of verification and } \\
\text { comparison of products }\end{array}$ & 7.43 & 1.85 & 6.48 & 1.48 & 0.94 & $<0.001$ \\
\hline Transaction speed & 6.98 & 2.09 & 6.20 & 1.53 & 0.78 & $<0.001$ \\
\hline $\begin{array}{l}\text { Possibility of withdrawal or } \\
\text { product return }\end{array}$ & 7.05 & 2.20 & 6.41 & 1.78 & 0.64 & 0.003 \\
\hline $\begin{array}{l}\text { Possibility to achieve assistance of } \\
\text { the seller }\end{array}$ & 7.11 & 2.11 & 7.94 & 1.16 & -0.83 & 0.019 \\
\hline General level of service & 7.56 & 1.68 & 8.52 & 0.57 & -0.96 & $<0.001$ \\
\hline
\end{tabular}

The results clearly demonstrated the presence of two areas in which there were important differences between the actual expectations of consumers and the trade companies perceptions of these expectations.

The first area was associated with a group of factors the meaning of which seemed tobe belittled by the companies. The group included all variables for which the level of consumers' expectations was significantly greater than the companies' 
assessments. The second area concerned the factors related to sales personnel, i.e., the possibility of obtaining the seller's help and the general perception of the level of service. With regard to these two factors, the expectations of consumers were significantly lower than their perception by the entities operating on the market (negative values of difference).

The answers of the two groups of respondents also were compared by using a statistical test, i.e., the Mann-Whitney U-value test, which was used due to the lack of normality of the distribution of the measured variables. The results of the test confirmed that a hypothesis on the unanimity of the two groups can be rejected for the majority of the variables that were examined.

The second group that was evaluated consisted of the factors (29 variables) that potentially affect the consumers' selection of a place for the transaction (Table 2).

Table 2 Factors Determining Selection of Place of Making a Purchase

\begin{tabular}{|c|c|c|c|c|c|c|}
\hline \multirow{2}{*}{ Factor } & \multicolumn{2}{|c|}{$\begin{array}{l}\text { Ratings of } \\
\text { consumers }\end{array}$} & \multicolumn{2}{|c|}{$\begin{array}{l}\text { Ratings of } \\
\text { companies }\end{array}$} & \multirow{2}{*}{$\begin{array}{c}\text { Difference } \\
\text { in average } \\
\text { rating }\end{array}$} & \multirow{2}{*}{$p$-value } \\
\hline & Avg. & $\begin{array}{l}\text { Std. } \\
\text { dev. }\end{array}$ & Avg. & $\begin{array}{l}\text { Std. } \\
\text { dev. }\end{array}$ & & \\
\hline Availability of rare products & 6.90 & 2.08 & 5.54 & 1.14 & 1.36 & $<0.001$ \\
\hline Information on website of the store & 7.09 & 1.99 & 6.02 & 1.39 & 1.07 & $<0.001$ \\
\hline Range of assortment & 7.41 & 1.69 & 6.54 & 1.11 & 0.87 & $<0.001$ \\
\hline $\begin{array}{l}\text { Possibility of checking the product } \\
\text { before purchase }\end{array}$ & 7.23 & 2.05 & 6.37 & 1.12 & 0.86 & $<0.001$ \\
\hline $\begin{array}{l}\text { Offered price promotions as well as } \\
\text { discounts }\end{array}$ & 7.38 & 1.65 & 6.54 & 1.28 & 0.85 & $<0.001$ \\
\hline Availability of products on-site & 7.31 & 1.97 & 6.78 & 1.55 & 0.54 & 0.001 \\
\hline Online sales & 6.87 & 2.11 & 6.33 & 1.21 & 0.54 & $<0.001$ \\
\hline Proximity of other IT stores & 5.35 & 2.52 & 4.81 & 1.58 & 0.53 & 0.021 \\
\hline $\begin{array}{l}\text { Presence in price comparing } \\
\text { websites }\end{array}$ & 6.12 & 2.42 & 5.61 & 1.62 & 0.51 & 0.001 \\
\hline $\begin{array}{l}\text { Time of existence of the company } \\
\text { on the market }\end{array}$ & 5.86 & 2.30 & 6.85 & 1.99 & -0.99 & 0.001 \\
\hline Level of service & 7.09 & 1.77 & 8.39 & 0.92 & -1.30 & $<0.001$ \\
\hline Physical size of the store & 5.03 & 2.47 & 6.39 & 1.69 & -1.36 & $<0.001$ \\
\hline
\end{tabular}

The situation in which the entities were not aware of the high importance of a specified factor occurred for nine of the 29 variables ("Availability of rare products" and others). Situations in which the companies attributed higher importance to factors than did the consumers who participated in the study were slightly less numerous. This was observed for three of the factors. The statistical test that was conducted 
(similarly, Mann-Whitney U-test) validated the assumption of the diversity of the ratings in the two groups for all factors listed previously.

The last area to be presented is the perceived customer service level and the importance of the factors that form its perception (Table 3, initially 10 variables).

Table 3 Factors Shaping Perception of The Level of Customer Service

\begin{tabular}{lccccccc}
\hline \multirow{2}{*}{ Factor } & \multicolumn{2}{c}{$\begin{array}{c}\text { Ratings of } \\
\text { consumers }\end{array}$} & \multicolumn{2}{c}{$\begin{array}{c}\text { Ratings of } \\
\text { companies }\end{array}$} \\
\cline { 2 - 7 } & Avg. $\begin{array}{c}\text { Std. } \\
\text { dev. }\end{array}$ & Avg. $\begin{array}{c}\text { Std. } \\
\text { in average } \\
\text { dev. }\end{array}$ & $p$-value \\
& 7.42 & 1.87 & 5.67 & 1.26 & 1.75 & $<0.001$ \\
\hline $\begin{array}{l}\text { Enabling checking a product in } \\
\text { the store }\end{array}$ & 7.42 & 1.89 & 6.83 & 1.84 & 0.58 & 0.006 \\
\hline $\begin{array}{l}\text { Not pushing consumer towards } \\
\text { selection }\end{array}$ & 7.52 & 1.75 & 8.07 & 1.04 & -0.56 & 0.088 \\
\hline $\begin{array}{l}\text { Personal culture (manners) of the } \\
\text { seller }\end{array}$ & & & & & & \\
\hline
\end{tabular}

It was interesting that, in this case, there were many less potential differences i.e., distinct discrepancies could be indicated only for three variables, one of which was not statistically significant.

\section{CONCLUSIONS}

The test results seem to provide definitive evidence that confirmed the existence of gaps in the companies' perceptions of the consumers' processes. The average difference of assessments of the two groups that were examined (with all variables included) was calculated taking into consideration the nature of the differences (positive or negative) amounted to 0.20 (for the first area that was presented), 0.15 (for the second area), and 0.07 (for the third area). These results indicated that, considering the examined area as a whole, the level of consumers' expectations was slightly higher than it was perceived to be among the companies. Thus, it is possible to propose the hypothesis that the companies believe that consumers have a slightly lower level of expectations than exists in reality.

The average size of the discrepancy, calculated as the average of absolute values of subsequent differences (between the assessments of consumers and those of the representatives of the companies) in the given area amounted to 0.59 in the case of consumer expectations with regard to the purchasing process, 0.52 for the factors that 
determine the selection of the place to make a purchase, and the same trend was evident for the factors that expressed the customer service level.

The observed differences lead to very interesting conclusions. The companies seem to:

(1) marginalize expectations of organizational nature, the fulfilment of which involves the expenditure of work and money and is substantially "uncomfortable," i.e., those concerning the specific functioning of a unit associated with reduction in income or associated with extending assortment;

(2) overestimate "soft" competencies, which are easy to develop and are related directly to the tasks being performed;

(3) shift the factors that form the results of the company and its relationship with customers beyond the area of responsibility of its employees (Table 2).

While the relative compliance in the third area (Table 3) was a consequence of a given situation in which the change of subsequent factors (except for the first one) did not require commitment of significant funds or introducing clear organizational changes.

In this case, one also can distinguish two models of companies' operations in the considered market. The first model, expected by customers, is a company that has a broad assortment of products that are currently available on-site, ensuring a sufficient level of information and a quick and safe transaction, supported with price-based promotion. The second of the aforementioned, i.e., functioning in the opinions of employees of companies, promotes large entities with a recognized brand that have been in the market for a long time, competing with a high level of service, but selling a narrow scope of assortment at unattractive prices. That model seems to be consistent with other research results and taxonomies that exist in this field (McLean and Blackie, 2004; Baden-Fuller and Mangematin, 2013).

Given the results that have been presented, a quite controversial question should be asked. Do the observed principles actually result from a deficit of knowledge among companies or are they a form of conscious or unconscious justification (to the environment and maybe to themselves) for not undertaking specific, troublesome, usually costly actions and an expression of aiming at improving the assessment of one's work. If the second answer is true, it means that the companies evade, for their own convenience, better compliance with the expectations of their customers, irrespective of the final cost-to-benefit ratio, i.e., the cost of decrease in turnover and 
loss of loyal customers to the benefits of lower financial encumbrances and psychological comfort.

Note that the above presentation features only some of the acquired results, i.e., within the study, measurements also were made for other areas of the behaviour of buyers. Among them, we observed many discrepancies between the opinions of companies' employees and the actual course of the consumers' acquisition processes.

\section{REFERENCES}

Antonides, G., \& Van Raaij, W. F. (1998). Consumer behaviour: a European perspective. Chichester: Wiley.

Baden-Fuller, C., \& Mangematin, V. (2013). Business models: A challenging agenda. Strategic Organization, 11(4), 418-427. http://dx.doi.org/10.1177/1476127013510112

Bethlehem, J. (2010). Selection bias in web surveys. International Statistical Review, 78(2), 161-188. http://dx.doi.org/10.1111/j.1751-5823.2010.00112.x

Bettman, J. R. (1979). Information processing theory of consumer choice. AddisonWesley

Blackwell, R. D., Miniard, P. W., \& Engel, J. F. (2001). Consumer behavior (9th). South-Western Thomas Learning. Mason, $\mathrm{OH}$.

Chua, A. Y., \& Banerjee, S. (2013). Customer knowledge management via social media: the case of Starbucks. Journal of Knowledge Management, 17(2), 237249. http://dx.doi.org/10.1108/13673271311315196

Etemad, H. (2004). E-commerce: The emergence of a field and its knowledge network. International Journal of Technology Management, 28(7), 776-800. http://dx.doi.org/10.1504/IJTM.2004.005783

Furrer, O., \& Sudharshan, D. (2001). Internet marketing research: opportunities and problems. Qualitative Market Research: An International Journal, 4(3), 123-129. http://dx.doi.org/10.1108/13522750110393026

Kardes, F. R., Cline, T. W., \& Cronley, M. L. (2011): Consumer behavior: Science and practice. Cincinnati, $\mathrm{OH}$ : South-Western, Cengage Learning.

Kotler, P. and Keller, KL (2006).

Marketing management (12th ed)., New Jersey: Pearson Prentice Hall.

MacInnis, D. J., \& Folkes, V. S. (2010). The disciplinary status of consumer behavior: A sociology of science perspective on key controversies. Journal of Consumer Research, 36(6), 899-914. http://dx.doi.org/10.1086/644610 
McLean, R., \& Blackie, N. M. (2004). Customer and company voices in e-commerce: a qualitative analysis. Qualitative Market Research: An International Journal, 7(4), 243-249. http://dx.doi.org/10.1108/13522750410557049

Piercy, N. (2009). Market-Led Strategic Change (4th ed.). Oxford: Elsevier.

Polish Central Statistical Office (2010). Wykorzystanie technologii informacyjnotelekomunikacyjnych $w$ przedsiębiorstwach $i$ gospodarstwach domowych $w$ 2009r. (tablice) [Utilisation of information and telecommunication technologies in polish companies and households in 2009], http://stat.gov.pl/.

Polish Office of Electronic Communications (2010). Oszacowanie przyszłej wielkości i tempa wzrostu na stacjonarne ustugi szerokopasmowe $w$ Polsce (lata 20102012) [An estimation of future size and grow rate of broadband Internet services in Poland (years 2010 and 2012)], http://www.uke.gov.pl.

Rosania T. M.(1995). Advertising, Wydawnictwo PWSBiA.

Rowley, J. (2002). Eight questions for customer knowledge management in ebusiness. Journal of Knowledge Management, 6(5), 500-511. http://dx.doi.org/10.1108/13673270210450441

Rowley, J., \& Slack, F. (2001). Leveraging customer knowledge-profiling and personalisation in e-business. International Journal of Retail \& Distribution Management, 29(9), 409-416. http://dx.doi.org/10.1108/09590550110400894

Sinkula, J. M. (2002). Market-based success, organizational routines, and unlearning. Journal of Business \& Industrial Marketing, 17(4), 253-269. http://dx.doi.org/10.1108/08858620210431660

Solomon M. R.(2007) Consumer Behaviour. Buying, Having and Being(7th edition). Pearson Prentice Hall.

Wilhelm, S., Gueldenberg, S., \& Güttel, W. (2013). Do you know your valuable customers?.Journal of Knowledge Management, 17(5), 661-676. http://dx.doi.org/10.1108/JKM-12-2012-0385

Zikmund, W. G. \& Babin, B.J. (2013). Essentials of Marketing Research (5th ed.). Mason, OH: South-Western/CENGAGE Learning. 
